\title{
Effect of Nitrogen and Sulphur Levels on Yield, Economics and Quality of QPM Hybrids under Dryland Condition of Eastern Uttar Pradesh, India
}

\author{
Sabha Jeet ${ }^{1}$, J. P. Singh ${ }^{2}$, Rakesh Kumar ${ }^{3}$, Rakesh Kumar Prasad ${ }^{4}$, Pramod Kumar ${ }^{5}$, Anupma Kumari ${ }^{6}$ \& Pravin \\ Prakash $^{2}$ \\ ${ }^{1}$ Subject Matter Specialist (Agronomy), Krishi Vigyan Kendra Halsi, Lakhisarai, Bihar Agricultural University \\ Sabour, Bhagalpur, India \\ ${ }^{2}$ Department of Agronomy, Institute of Agricultural Sciences, B. H. U. Varanasi 221005, India \\ ${ }^{3}$ Scientist (Agronomy), ICAR Research Complex for NEH Region, Nagaland Centre Jharnapani, Medziphema \\ 797106, Nagaland, India \\ ${ }^{4}$ Subject Matter Specialist (Soil - Science), Krishi Vigyan Kendra Vikramganj, Bihar Agricultural University \\ Sabour, Bhagalpur, India \\ ${ }^{5}$ Subject Matter Specialist (Agronomy), Krishi Vigyan Kendra Jagannathpur 833203, Birsa Agricultural \\ University, Ranchi, India \\ ${ }^{6}$ Subject Matter Specialist (Agronomy), Krishi Vigyan Kendra, Vaishali Rajendra Agricultural University, Pusa, \\ Samastipur 848125, India \\ Correspondence: Sabha Jeet, Subject Matter Specialist (Agronomy), Krishi Vigyan Kendra Halsi, Lakhisarai, \\ Bihar Agricultural University Sabour, Bhagalpur, India. E-mail: agrisabhaj@gmail.com
}

Received: March 14, 2012 Accepted: April 10, 2012 Online Published: July 26, 2012

doi:10.5539/jas.v4n9p31 URL: http://dx.doi.org/10.5539/jas.v4n9p31

\begin{abstract}
The effect of four nitrogen levels $\left\{0 \mathrm{~kg} \mathrm{~N} h a^{-1}\left(\mathrm{~N}_{0}\right), 50 \mathrm{~kg} \mathrm{~N} \mathrm{ha}^{-1}\left(\mathrm{~N}_{1}\right), 100 \mathrm{~kg} \mathrm{~N} \mathrm{ha}^{-1}\left(\mathrm{~N}_{2}\right)\right.$ and $\left.150 \mathrm{~kg} \mathrm{~N} \mathrm{ha}^{-1}\left(\mathrm{~N}_{3}\right)\right\}$ two QPM hybrids $\left\{\right.$ Shaktiman-2 $\left(\mathrm{G}_{1}\right)$ and Shaktiman-4 $\left.\left(\mathrm{G}_{2}\right)\right\}$ and three levels of sulphur $\left\{15 \mathrm{~kg} \mathrm{Sha}^{-1}\left(\mathrm{~S}_{1}\right), 30 \mathrm{~kg}\right.$ $\mathrm{S} \mathrm{ha}^{-1}\left(\mathrm{~S}_{2}\right)$ and $\left.45 \mathrm{~kg} \mathrm{Sha}^{-1}\left(\mathrm{~S}_{3}\right)\right\}$ in quality protein maize $(\mathrm{QPM})$ production for two years on an experimental field (Sandy clay loam) located at Agricultural Dryland Research Farm, Institute of Agricultural Sciences, Banaras Hindu University, Varanasi, India. Each treatment was replicated three times in split plot design. The aim of research was to determine the influence of nitrogen and sulphur levels on yield, quality and economics of QPM hybrids under dryland condition. The significantly highest plant height, leaf area index (LAI), yield, net returns, benefit: cost ratio (B: C), lysine and tryptophan content were recorded with $150 \mathrm{~kg} \mathrm{~N} \mathrm{ha}^{-1}\left(\mathrm{~N}_{150}\right)$ as compared to $\mathrm{N}_{100}, \mathrm{~N}_{50}$ and $\mathrm{N}_{0}$. On average QPM hybrids, Shaktiman-4 produced significantly taller plant $(171.68 \mathrm{~cm})$, higher LAI (5.49), grain yield (60.54 $\left.\mathrm{q} \mathrm{ha}^{-1}\right)$, net return (Rs. $36246.01 \mathrm{ha}^{-1}$ ), B: C ratio (2.22), tryptophan content (0.77\%) and lysine content (3.88) than Shaktiman-2. Sulphur analysis also recorded that the significantly taller plant $(173.88 \mathrm{~cm})$, highest LAI (5.58), grain yield $\left(61.67 \mathrm{q} \mathrm{ha}^{-1}\right)$, net returns ( $\left.37943.30 \mathrm{ha}^{-1}\right)$, B: C ratio (2.25), tryptophan content $(0.78 \%)$ and lysine content (3.88) were recorded under $45 \mathrm{~kg} \mathrm{Sha}^{-1}$ and lowest were recorded at $15 \mathrm{Kg} \mathrm{S} \mathrm{ha}^{-1}$. Interaction effect of $\mathrm{N}_{150} \times \mathrm{S}_{45}$ obtained significantly taller plant $(197.00 \mathrm{~cm})$, higher LAI (6.71), grain yield (69.14 q ha ${ }^{-1}$ ), net return (Rs. $56075.52 \mathrm{ha}^{-1}$ ), B: C ratio (2.68), tryptophan content $(0.83 \%)$ and lysine content (3.99) than $\mathrm{N}_{3} \times \mathrm{S}_{1}$. Result revealed that, interaction effect of Shaktiman- $4 \times \mathrm{S}_{45}$ obtained significantly taller plant $(177.68 \mathrm{~cm})$, higher LAI (5.79), grain yield $\left(62.35 \mathrm{q} \mathrm{ha}^{-1}\right)$, net return (Rs. $\left.39825.09 \mathrm{ha}^{-1}\right), \mathrm{B}: \mathrm{C}$ ratio (2.26), tryptophan content $(0.79 \%)$ and lysine content (3.91) than Shaktiman- $2 \times \mathrm{S}_{15}$.
\end{abstract}

Keywords: QPM hybrid, nitrogen, sulphur, grain yield, economics, lysine and tryptophan

\section{Introduction}

Queen of cereals maize is so named because of its unbelievably high yield potential that out yields any other cereal crop. This potential of maize cannot be manifested up to the brim due to several biotic and a biotic factors amongst which poor nutritional management and selection of QPM hybrid is the prime one. Thus proper nutrition and good QPM hybrid is very important to get high crop production. Nitrogen is a vital plant nutrient and a major yield determining factor required for maize production. It is very essential for plant growth and makes up 1 to 4 percent 
of dry matter of the plants. Nitrogen is a component of protein and nucleic acids and when nitrogen is sub-optimal, growth is reduced. Its availability in sufficient quantity throughout the growing season is essential for optimum maize growth. It is also characteristic constituent element of proteins and also an integral component of many other compounds essential for plant growth processes including chlorophyll and many enzymes (Onasanya et al., 2009). Sulphur nutrition help the plants to perform many physiological functions like synthesis of sulphur containing amino acids namely, cystein, cystine, methionine etc. Synthesis of protein occurs in to leaves, hence sulphur deficiency leads chlorosis in younger leaves. The concentration of sulphur in vegetative tissue usually ranges $0.2-0.5 \%$ on the dry weight basis. Thus, plant a requirement for available sulphur is mainly responsible for nitrogen availability, hence with increasing rate of sulphur the availability and uptake of $\mathrm{N}$ is increased (Mehta et al., 2005). Important of protein quality of cereals by genetic modifications or agronomic intervention is a potentially use full means of preventing and alleviating protein malnutrition in young children. Corn (Zea mays L.), which is the third ranking food crop in the world, is a major source of protein for many pre-school children in central and South America and elsewhere. Opaque2 maize, which is higher in lysine and tryptophan and lower in leucine than in common maize has been successfully as the only source of protein for pre-school children in several countries (Lucia et al., 1976). The concentration of lysine and tryptophan, essential limiting amino acids in maize, was determined for both QPM hybrids. In India, $2 / 3^{\text {rd }}$ of total cultivated land is rainfed which contributes about $44 \%$ of the country food requirement. In such areas crop production become relatively difficult due to irregular weather conditions, degraded soil having low inherent fertility. Rice- wheat and Maize-wheat is the traditional cropping sequence in rainfed areas of India. The yield of crops in rainfed areas remains stagnant due to water stress and seasonal agricultural drought owing to low and erratic rainfall, high runoff water losses and high evaporation. These soils are light in texture, infertile and deficient in nitrogen, phosphorus and sulphur (Sharma et al., 2011). In view of the above present investigation was aim to determine effect of nitrogen and sulphur on grain yield, economics and quality of quality protein maize (QPM) QPM hybrids under dryland conditions.

\section{Materials and Methods}

\subsection{Experimental Site, Climate and Soil}

The experiment was conducted at Dryland Agriculture Research Farm, Institute of Agricultural Sciences, Banaras Hindu University, Varanasi, India, during 2009-2010 and 2010-2011 under dryland conditions. It is located on $25^{\circ}$ $18^{\prime} \mathrm{N}$ latitude, $83^{\circ} 3^{\prime} \mathrm{E}$ longitude and at altitude of 141.3 meters above mean sea level in the Northern Gangetic alluvial plains of India. The soil was sandy clay loam (Course sand $7.59 \%$, Fine sand $50.50 \%$, Silt $23.45 \%$ and clay $18.25 \%$ ) in texture having $\mathrm{pH} 7.6, \mathrm{EC} 0.61 \mathrm{dSm}^{-1}$, organic carbon $0.35 \%$, available nitrogen $183.0 \mathrm{~kg} \mathrm{ha}^{-1}$, available $\mathrm{P}_{2} \mathrm{O}_{5} 21.02 \mathrm{~kg} \mathrm{ha}^{-1}$, available $\mathrm{K}_{2} \mathrm{O} 228.00 \mathrm{~kg} \mathrm{ha}^{-1}$ and available $\mathrm{S} 14.32 \mathrm{~kg} \mathrm{ha}^{-1}$ followed by cool to warm weather period from December to June. The total rainfall received during crop period June, 2009 to December, 2009 and June, 2010 to December, 2010 was $484.2 \mathrm{~mm}$ and $722.00 \mathrm{~mm}$, respectively.

\subsection{Experimental Details}

The experiment was conducted in split plot design replicated three times with four nitrogen levels $\left[0 \mathrm{~kg} \mathrm{ha}^{-1}\left(\mathrm{~N}_{0}\right), 50\right.$ $\mathrm{kg} \mathrm{ha}^{-1}\left(\mathrm{~N}_{1}\right), 100 \mathrm{~kg} \mathrm{ha}^{-1}\left(\mathrm{~N}_{2}\right), 150 \mathrm{~kg} \mathrm{ha}^{-1}\left(\mathrm{~N}_{3}\right)$ ] in main plot treatments, two QPM hybrids [Shaktiman-2 $\left(\mathrm{G}_{1}\right)$ and Shaktiman-4 $\left(\mathrm{G}_{2}\right)$ and three sulphur levels $\left[15 \mathrm{~kg} \mathrm{ha}^{-1}\left(\mathrm{~S}_{1}\right), 30 \mathrm{~kg} \mathrm{ha}^{-1}\left(\mathrm{~S}_{2}\right)\right.$ and $\left.45 \mathrm{~kg} \mathrm{ha}^{-1}\left(\mathrm{~S}_{3}\right)\right]$ in sub plots. The dimensions of individual plot were $5.0 \mathrm{~m} \times 3.60 \mathrm{~m}$. The residual effect of these treatments was studies in next succeeding maize crop. Despite nitrogen and sulphur treatments a recommended dose of diammonium phosphate $\left(60 \mathrm{~kg} \mathrm{ha}^{-1}\right)$ and Muriate of potash $\left(40 \mathrm{~kg} \mathrm{ha}^{-1}\right)$ were applied. Bed preparation was done with tractor drawn bed-maker-cum-planter. Distance of $67.5 \mathrm{~cm}$ between centre to centre of bed the bed size including $37.5 \mathrm{~cm}$ bed top and $30 \mathrm{~cm}$ furrow. One row bed ${ }^{-1}$ of crop was sown. The spacing of $67.5 \mathrm{~cm} \times 22 \mathrm{~cm}$ was maintained by thinning and gap filling. QPM hybrids involving opaque 2 viz., Shaktiman-2 and Shaktiman-4 of full season maturity during kharif season were sown. Recommended seed rates of QPM $25 \mathrm{~kg} \mathrm{ha}^{-1}$ were sown. Seed was treated with capton @ $3 \mathrm{~g} \mathrm{~kg}^{-1}$ of seed before sowing to avoid the diseases problems.

\subsection{Observations Recorded}

Height of the randomly selected and marked five plants was measured at 30 days interval and at harvest. The plant height was measured from the base of the plant to the tip of the upper most leaf. Periodic leaf area of two randomly selected plants was measured with the help of Delta-T Image Analyzer at 30 days interval. From leaf area values the leaf area index was calculated as described by Radford (1967). LAI was calculated by dividing Leaf area $\left(\mathrm{cm}^{2}\right) /$ land area covered by plant $\left(\mathrm{cm}^{2}\right)$. Estimation of tryptophan and lysine in defatted samples were estimated by the colorimetric methods as described by Hernandez and Bates (1969) and Villegas and Mertz (1971), respectively. Net return $\left(\mathrm{Rs}^{\mathrm{a}} \mathrm{a}^{-1}\right)$ was calculated by deducted gross return $\left(\right.$ Rs. ha $\left.{ }^{-1}\right)$ to cost of cultivation (Rs. ha $\left.{ }^{-1}\right)$ while benefit: cost ratio was estimated by divided gross return (Rs. ha ${ }^{-1}$ ) to cost of cultivation (Rs. ha ${ }^{-1}$ ). 


\subsection{Statistical Analysis}

Statistical analysis was carried out to know the variance for different parameters. To test the significance, the experimental data collected on various aspects of the investigation on maize and soil were statistically analysed with the procedure described by Cochran \& Cox (1967) and adopted by Cheema and Singh (1991) in statistical package CPCS-1. All the comparisons were made at $5 \%$ level of significance.

\section{Results and Discussion}

\subsection{Growth}

Pooled data of 2 years showed that the nitrogen, QPM hybrids and sulphur levels had significant effect on growth. Plant height is a useful index of the developmental phases of the plant to give an idea about dry matter production leading to ultimate yield. The highest average plant height $(191.62 \mathrm{~cm})$ was recorded with $150 \mathrm{~kg} \mathrm{~N} \mathrm{ha}^{-1}\left(\mathrm{~N}_{3}\right)$ which proved significantly superior over rest of treatments. The lowest plant height of $138.58 \mathrm{~cm}$ was recorded in $\mathrm{N}_{0}$ treatments (Figure 1). It may be owing to the beneficial effect of nitrogen for plant metabolism which affect physiological process of the crop and increase plant height. The greater residual uptake of nitrogen was also reported with the increase in the rates of nitrogen application leading to taller plant was reported by Lohry, (1990) and Gaur et al., (1992). Among the QPM hybrids Shaktiman-4 significantly improved plant height $171.68 \mathrm{~cm}$ than Shaktiman-2. QPM hybrid, Shaktiman-4 recorded 3.16\% taller plant height over Shaktiman-2 (Figure 2). Among sulphur treatments, $S_{45}$ treatments significantly recorded taller plant height followed by $S_{30}$ and $S_{15}$, respectively. However, interaction of sulphur at same level of nitrogen on plant height was also observed significant. Treatment $\mathrm{S}_{45} \times \mathrm{N}_{150}$ recorded taller plant height $(197.0 \mathrm{~cm})$ than $\mathrm{S}_{15} \times \mathrm{N}_{150}$ but it was at par with $\mathrm{S}_{30} \times \mathrm{N}_{150}$ (Figure 2). Application of $45 \mathrm{~kg} \mathrm{~S} h a^{-1}$ produced taller plant height $6.38 \%$ over $15 \mathrm{~kg} \mathrm{Sha}^{-1}$. Combined use of $150 \mathrm{~kg} \mathrm{~N} \mathrm{ha}^{-1} \mathrm{x}$ $45 \mathrm{~kg} \mathrm{~S} \mathrm{ha}^{-1}$ recorded significantly taller plants over $150 \mathrm{~kg} \mathrm{~N} \mathrm{ha}^{-1} \times 15 \mathrm{~kg} \mathrm{~S} \mathrm{ha}^{-1}$ (Figure 1). Similar results were observed by Sinha et al., (1995). Leaf area index (LAI) is an important plant index, determining the capacity of plants in trapping solar energy for photosynthesis. $\mathrm{N}_{150}$ observed significantly highest average mean of LAI followed by $\mathrm{N}_{100}, \mathrm{~N}_{50}$ and $\mathrm{N}_{0}$. Significantly more average mean of LAI was obtained under Shaktiman- 4 treatment than Shaktiman- 4. $\mathrm{S}_{45} \times \mathrm{N}_{150}$ recorded more LAI (6.71) than $\mathrm{S}_{1} \times \mathrm{N}_{3}$ but it was found to be non significant with $\mathrm{S}_{30}$ $\mathrm{x} \mathrm{N}_{150}$ (Figure 3).

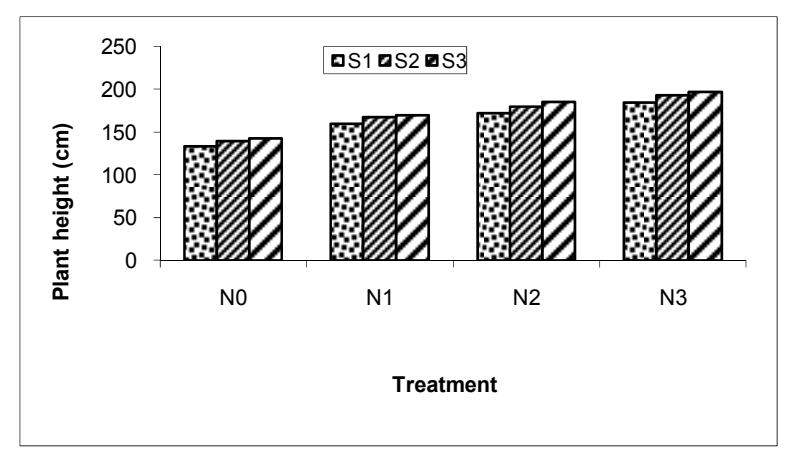

Figure 1. Effect of nitrogen and sulphur on plant height $(\mathrm{cm})$ at harvesting of QPM hybrids (2 years average) where $\mathrm{S}_{1=} 15 \mathrm{~kg} \mathrm{Sha}^{-1}, \mathrm{~S}_{2}=30 \mathrm{~kg} \mathrm{ha}^{-1}, \mathrm{~S}_{3=} 45 \mathrm{~kg} \mathrm{ha}^{-1}, \mathrm{~N}_{0=} 0 \mathrm{~kg} \mathrm{~N} \mathrm{ha}^{-1}, \mathrm{~N}_{1=} 50 \mathrm{~kg} \mathrm{~N} \mathrm{ha}^{-1}, \mathrm{~N}_{2=} 100 \mathrm{~kg} \mathrm{~N}^{-1}$ and $\mathrm{N}_{3=}$ $150 \mathrm{~kg} \mathrm{~N} \mathrm{ha}^{-1}$. C.D. $(P=0.05) \mathrm{N}=8.88 \mathrm{~S}=7.33 \mathrm{~S}$ at $\mathrm{N}=10.98$

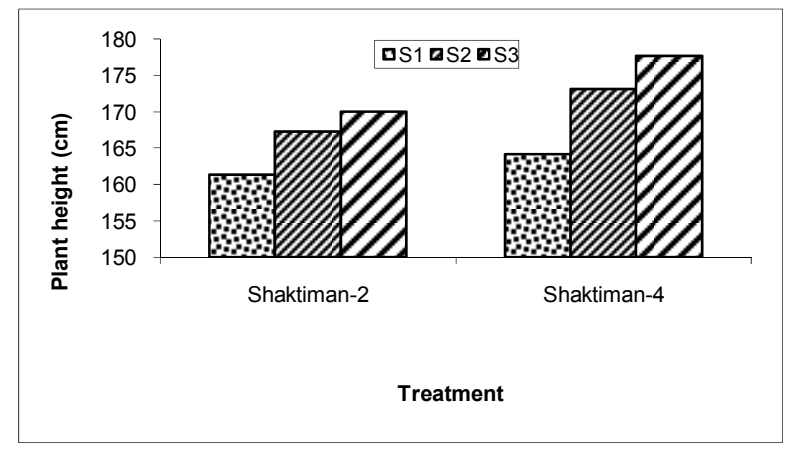

Figure 2. Effect of QPM hybrids and sulphur on plant height $(\mathrm{cm})$ at harvesting (2 years average) where $\mathrm{S}_{1=} 15$ $\mathrm{kg} \mathrm{Sha}^{-1}, \mathrm{~S}_{2}=30 \mathrm{~kg} \mathrm{ha}^{-1}$ and $\mathrm{S}_{3=}=45 \mathrm{~kg} \mathrm{ha}^{-1}$. C.D. $(P=0.05) \mathrm{G}=4.11 \mathrm{~S}=3.83 \mathrm{~S}$ at $\mathrm{G}=8.93$ 


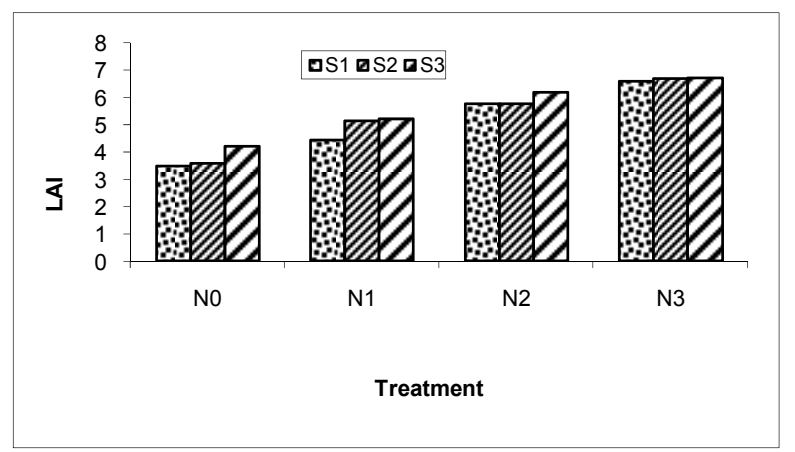

Figure 3. Effect of nitrogen and sulphur on leaf area index (LAI) at harvesting of QPM hybrids (2 years average) where $\mathrm{S} 1=15 \mathrm{~kg} \mathrm{~S}$ ha- $1, \mathrm{~S} 2=30 \mathrm{~kg}$ ha- $1, \mathrm{~S} 3=45 \mathrm{~kg}$ ha- $1, \mathrm{~N} 0=0 \mathrm{~kg} \mathrm{~N}$ ha-1, N1= $50 \mathrm{~kg} \mathrm{~N}$ ha-1, N2= $100 \mathrm{~kg} \mathrm{~N}$ ha-1 and $\mathrm{N} 3=150 \mathrm{~kg} \mathrm{~N}$ ha-1. C.D. $(\mathrm{P}=0.05) \mathrm{N}=4.71 \mathrm{~S}=0.42 \mathrm{~S}$ at $\mathrm{N}=0.11$

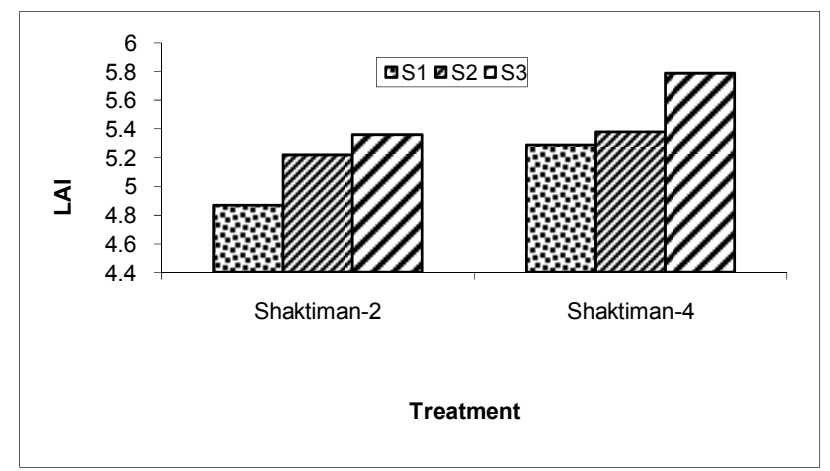

Figure 4. Effect of QPM hybrids and sulphur on leaf area index $(\mathrm{LAI})$ at harvesting (2 years average) where $\mathrm{S} 1=$ $15 \mathrm{~kg} \mathrm{~S}$ ha-1, $\mathrm{S} 2=30 \mathrm{~kg}$ ha- 1 and $\mathrm{S} 3=45 \mathrm{~kg}$ ha-1. C.D. $(\mathrm{P}=0.05) \mathrm{G}=0.28 \mathrm{~S}=0.42 \mathrm{~S}$ at $\mathrm{G}=0.49$

\subsection{Yield}

Pooled data of 2 years showed that the nitrogen, QPM hybrids and Sulphur levels had significant effect on grain yield. Grain yield of QPM hybrids was significantly affected by different nitrogen levels (Table 1). The highest average grain yield $\left(67.3 \mathrm{q} \mathrm{ha}^{-1}\right)$ was recorded under $150 \mathrm{~kg} \mathrm{~N} \mathrm{ha}^{-1}$ which proved significantly superior over rest of nitrogen treatments. The lowest grain yield of $5073 \mathrm{~kg} \mathrm{ha}^{-1}$ was recorded in $\mathrm{N}_{0}$ treatments. The magnitude of increase of grain yield was to be extent of $24.62 \%$ with the $\mathrm{N}_{150}$ application over $\mathrm{N}_{0}$ (Table 1). It may be owing to the beneficial effect of nitrogen for plant metabolism which affect physiological process of the crop and increase grain yield. Many researchers reported that a greater yield can be achieved with $150 \mathrm{~kg} \mathrm{~N}^{-1}$ as compared to the rest of treatments. Abdel-Wahab et al., (2008) reported that in maize production the highest yield has been obtained with $120 \mathrm{~kg} \mathrm{~N} \mathrm{fed}^{-1}$ than 60 and $90 \mathrm{~kg} \mathrm{~N} \mathrm{fed}^{-1}$ led to increase the grain yield by $174.77 \%, 103.70 \%$ and $141.12 \%$, respectively over control. Maurya et al., (2005) also reported that highest grain yields $\left(4644 \mathrm{~kg} \mathrm{ha}^{-1}\right)$ were obtained with the application of $150 \mathrm{~kg} \mathrm{~N} \mathrm{ha}^{-1}$. The conformity of result of present investigation was also reported by Bhat et al., (2008) and Rana and Choudhary, (2006). Among the QPM hybrids Shaktiman-4 significantly improved grain yield of $60.54 \mathrm{q} \mathrm{ha}^{-1}$ than Shaktiman-2 with grain yield of $59.40 \mathrm{q} \mathrm{ha}^{-1}$. Whereas, percent increase in grain yield of Shaktiman- 4, 2.04\% higher than Shaktiman-2 (Table 2). Pixley and Bjarnason (2002) reported 13 per cent higher grain yield in hybrids than OPCS (Open pollinated cultivars) which obtained $9460 \mathrm{~kg} \mathrm{ha}^{-1}$ and $9240 \mathrm{~kg} \mathrm{ha}^{-1}$, respectively. Upadhyay et al., (2008) recorded grain yield was significantly highest in 2 QPM hybrids (SO3 TLWQ-AB-01 and Obatampa) than the local check. Similar result also reported by Srivastava et al., (2005) and San Vicente et al., (2005). Sulphur treatments brought about significant effect on grain yield. Among sulphur treatments, $45 \mathrm{~kg} \mathrm{~S}^{-1}$ significantly improved grain yield of $61.66 \mathrm{q} \mathrm{ha}^{-1}$ followed by $30 \mathrm{~kg}$ $\mathrm{S} \mathrm{ha}^{-1}$ and $15 \mathrm{~kg} \mathrm{Sha}^{-1}$ with grain yield of $60.02 \mathrm{q} \mathrm{ha}^{-1}$ and $58.23 \mathrm{q} \mathrm{ha}^{-1}$, respectively (Table 1). It may be owing to help the plants to perform many physiological functions and yield. Maurya et al., (2005) reported that in maize production the highest yield had been obtained with $45 \mathrm{~kg} \mathrm{Sha}^{-1}$. The interaction effect of $\mathrm{N} \mathrm{x} \mathrm{S}$ and G x S on QPM hybrids in respect of yield was also significant. The significantly highest value of grain yield $69.14 \mathrm{q} \mathrm{ha}^{-1}$ was 
obtained incase of $150 \mathrm{~kg} \mathrm{~N} h a^{-1}\left(\mathrm{~N}_{3}\right)$ in combination with $45 \mathrm{~kg} \mathrm{Sha}^{-1}\left(\mathrm{~S}_{3}\right)$ than $\mathrm{S}_{30} \times \mathrm{N}_{150}$ (Table 1). Interaction effect of nitrogen $\times$ sulphur, QPM hybrids $x$ sulphur was found to be significant. Treatment $150 \mathrm{~kg} \mathrm{~N} \mathrm{ha}^{-1} \times 45 \mathrm{~kg}$ $\mathrm{S} \mathrm{ha}^{-1}$ recorded significantly highest grain yield which proved $5.51 \%$ over $150 \mathrm{~kg} \mathrm{~N} \mathrm{ha}^{-1} \times 15 \mathrm{~kg} \mathrm{~S} \mathrm{ha}^{-1}$ (Table 1). Similarly, treatment $\mathrm{S}_{45} \times$ Shatiman-4 obtained $5.54 \%$ higher grain yield over $\mathrm{S}_{15} \times$ Shatiman-4 (Table 2). Similar result was also found that application of $S$ at $45 \mathrm{~kg} \mathrm{ha}^{-1}$ significantly increased seed yields (Bharathi and Poongothai, 2008). The beneficial effect of nitrogen and sulphur on QPM hybrids could be attributed to change physiological process, enhancing bio-available concentration and increase grain yield.

Table 1. Interaction effect of nitrogen and sulphur on grain yield ( $\left.\mathrm{q} \mathrm{ha}^{-1}\right)$ of QPM hybrids (average of two years).

\begin{tabular}{|c|c|c|c|c|}
\hline \multirow[t]{2}{*}{ Treatment } & \multicolumn{3}{|c|}{ Grain yield $\left(q \mathrm{ha}^{-1}\right)$} & \multirow[t]{2}{*}{ Mean } \\
\hline & $15 \mathrm{~kg} \mathrm{~S} \mathrm{ha}^{-1}$ & $30 \mathrm{~kg} \mathrm{~S} \mathrm{ha}^{-1}$ & $45 \mathrm{~kg} \mathrm{~S} \mathrm{ha}^{-1}$ & \\
\hline $0 \mathrm{~kg} \mathrm{~N} \mathrm{ha}^{-1}$ & 49.11 & 50.64 & 52.43 & 50.73 \\
\hline $50 \mathrm{~kg} \mathrm{~N} \mathrm{ha}^{-1}$ & 57.09 & 58.61 & 60.40 & 58.70 \\
\hline $100 \mathrm{~kg} \mathrm{~N} \mathrm{ha}^{-1}$ & 61.37 & 63.40 & 64.67 & 63.15 \\
\hline $150 \mathrm{~kg} \mathrm{~N} \mathrm{ha}^{-1}$ & 65.33 & 67.42 & 69.14 & 67.30 \\
\hline Mean & 58.23 & 60.02 & 61.66 & \\
\hline C.D. (0.05) & \multicolumn{3}{|c|}{$\mathbf{N}=4.10 \mathrm{~S}=3.12 \mathrm{~S}$ at $\mathrm{N}=3.25$} & \\
\hline
\end{tabular}

$\mathrm{N}=$ Nitrogen levels $\mathrm{S}=$ Sulphur levels $\mathrm{S}$ at $\mathrm{N}=$ Interaction of nitrogen at same level of sulphur.

Table 2. Interaction effects of QPM hybrids and sulphur on grain yield ( $\mathrm{q} \mathrm{ha}^{-1}$ ) (average of two years)

\begin{tabular}{lcccc}
\hline \multirow{2}{*}{ Treatment } & \multicolumn{3}{c}{ Grain yield (q ha $\left.\mathbf{~}^{-\mathbf{1}}\right)$} & \multirow{2}{*}{ Mean } \\
\cline { 2 - 4 } & $\mathbf{1 5} \mathbf{~ k g ~ h a}^{\mathbf{- 1}}$ & $\mathbf{3 0 ~ \mathbf { ~ k g ~ h a }}$ & $\mathbf{4 5} \mathbf{~ k g ~ h a}^{-\mathbf{1}}$ & \\
\hline Shaktiman-2 & 57.56 & 59.67 & 60.98 & 59.40 \\
Shaktiman-4 & 58.89 & 60.37 & 62.35 & 60.54 \\
Mean & 58.23 & 60.02 & 61.67 & \\
C.D. (0.05) & $\mathbf{G}=1.12 \mathrm{~S}=3.12 \mathrm{~S}$ at G=3.21 & \\
\hline
\end{tabular}

$\mathrm{G}=\mathrm{QPM}$ hybrids $\mathrm{S}=$ Sulphur levels $\mathrm{S}$ at $\mathrm{G}=$ Interaction of QPM hybrids at same level of sulphur.

\subsection{Quality}

Pooled data on 2 years showed that at different levels of nitrogen, $150 \mathrm{~kg} \mathrm{ha}^{-1}\left(\mathrm{~N}_{3}\right)$ gave remarkably highest lysine content $3.96 \%$ which was significantly superior over $100 \mathrm{~kg} \mathrm{~N} \mathrm{ha}^{-1}\left(\mathrm{~N}_{2}\right)$ and $50 \mathrm{~kg} \mathrm{ha}^{-1}\left(\mathrm{~N}_{1}\right)$. The lowest lysine content was recorded in $0 \mathrm{~kg} \mathrm{~N} h a^{-1}\left(\mathrm{~N}_{0}\right)$. $\mathrm{N}_{150}$ registered $5.80 \%$ higher lysine content over $\mathrm{N}_{0}($ Table 3$)$. The conformity of result of present investigation was also reported by Rasheed et al., (2004). The lysine content of QPM hybrid Shaktiman-4 recorded significantly highest 3.88\% over Shaktiman-2 3.82\% (Table 4). This might be due to higher nitrogen and sulphur uptake enhances these concentrations and increases these attributes content in grain significantly. The conformity of result of present investigation was also made by Gupta et al., (2009). Among sulphur treatments, significantly highest lysine content $3.88 \%$ was recorded with application $45 \mathrm{~kg} \mathrm{~S}^{-1}$ followed by $30 \mathrm{~kg} \mathrm{Sha}^{-1} 3.85 \%$ and $15 \mathrm{~kg} \mathrm{Sha}^{-1} 3.82 \%$ (Table 3). The interaction effect of nitrogen (N) x sulphur (S) proved significant effect on lysine content. The significantly highest lysine content 3.99\% was obtained in combination with $150 \mathrm{~kg} \mathrm{~N} \mathrm{ha}^{-1}\left(\mathrm{~N}_{3}\right) \times 45 \mathrm{~kg} \mathrm{Sha}^{-1}\left(\mathrm{~S}_{3}\right)$, while the lowest value of lysine $3.93 \%$ was observed with $150 \mathrm{~kg} \mathrm{~N} \mathrm{ha}^{-1}$ $\left(\mathrm{N}_{3}\right) \times 15 \mathrm{~kg} \mathrm{~S} \mathrm{ha}^{-1}\left(\mathrm{~S}_{3}\right)$ but it was found to be non significant with $\mathrm{N}_{3} \times \mathrm{S}_{2}$ (Table 3). Similar result also reported by Sakal et al., (2000). Data pertaining to tryptophan content (\%) as affected by nitrogen levels. Treatment $150 \mathrm{~kg} \mathrm{~N}$ $\mathrm{ha}^{-1}$ recorded significantly highest tryptophan content $0.81 \%$ over $100 \mathrm{~kg} \mathrm{~N} \mathrm{ha}^{-1}$ and $50 \mathrm{~kg} \mathrm{~N}^{-1}$. The lowest tryptophan $0.71 \%$ was obtained with $0 \mathrm{~kg} \mathrm{~N} \mathrm{ha}^{-1}$. In contrast, $150 \mathrm{~kg} \mathrm{~N} \mathrm{ha}^{-1}$ showed $2.34 \%$ higher tryptophan content over $0 \mathrm{~kg} \mathrm{~N} \mathrm{ha}^{-1}$ (Table 3). The QPM hybrid Shaktiman-4 recorded significantly higher tryptophan content $0.77 \%$ over Shaktiman-2 $0.75 \%$ (Table 4). Among sulphur treatments $45 \mathrm{~kg} \mathrm{~S} \mathrm{ha}^{-1}\left(\mathrm{~S}_{3}\right)$ remarkably higher tryptophan content $0.78 \%$ which was significantly superior over $30 \mathrm{~kg} \mathrm{~S} \mathrm{ha}^{-1} 0.76 \%$ and $15 \mathrm{~kg} \mathrm{~S} \mathrm{ha}^{-1} 0.74 \%$. The significantly highest tryptophan content $0.79 \%$ was obtained in combination with $150 \mathrm{~kg} \mathrm{~N} \mathrm{ha}^{-1}\left(\mathrm{~N}_{3}\right) \times 45 \mathrm{~kg} \mathrm{Sha}^{-1}$ 
$\left(\mathrm{S}_{3}\right)$, while the lowest value of tryptophan $0.75 \%$ was observed with $150 \mathrm{~kg} \mathrm{Nha}^{-1}\left(\mathrm{~N}_{3}\right) \times 15 \mathrm{~kg} \mathrm{Sha}^{-1}\left(\mathrm{~S}_{3}\right)$ but it was at par with $\mathrm{N}_{3} \times \mathrm{S}_{2}$ (Table 3). The findings indicate that the $150 \mathrm{~kg} \mathrm{~N}^{-1}$ with $45 \mathrm{~kg} \mathrm{~S}^{-1}$ was beneficial in term of grain yield and quality of QPM hybrids under dryland condition.

Table 3. Interaction effect of nitrogen and sulphur on lysine (\%) and tryptophan (\%) of QPM hybrids (average of two years)

\begin{tabular}{|c|c|c|c|c|c|c|c|c|}
\hline \multirow[t]{2}{*}{ Treatment } & \multicolumn{4}{|c|}{ Lysine (\%) } & \multicolumn{4}{|c|}{ Tryptophan (\%) } \\
\hline & $\begin{array}{c}15 \mathrm{~kg} \mathrm{~S} \\
\mathrm{ha}^{-1}\end{array}$ & $\begin{array}{c}30 \mathrm{~kg} \mathrm{~S} \\
\mathrm{ha}^{-1}\end{array}$ & $\begin{array}{c}45 \mathrm{~kg} \mathrm{~S} \\
\mathrm{ha}^{-1}\end{array}$ & Mean & $\begin{array}{c}15 \mathrm{~kg} \mathrm{~S} \\
\mathrm{ha}^{-1}\end{array}$ & $\begin{array}{c}30 \mathrm{~kg} \mathrm{~S} \\
\text { ha }^{-1}\end{array}$ & $\begin{array}{c}45 \mathrm{~kg} \mathrm{~S} \\
\mathrm{ha}^{-1}\end{array}$ & Mean \\
\hline $0 \mathrm{~kg} \mathrm{ha}^{-1}$ & 3.70 & 3.73 & 3.76 & 3.73 & 0.69 & 0.71 & 0.73 & 0.71 \\
\hline $50 \mathrm{~kg} \mathrm{ha}^{-1}$ & 3.80 & 3.83 & 3.86 & 3.83 & 0.72 & 0.74 & 0.76 & 0.74 \\
\hline $100 \mathrm{~kg} \mathrm{ha}^{-1}$ & 3.84 & 3.87 & 3.9 & 3.87 & 0.75 & 0.77 & 0.79 & 0.77 \\
\hline $150 \mathrm{~kg} \mathrm{ha}^{-1}$ & 3.93 & 3.96 & 3.99 & 3.96 & 0.79 & 0.81 & 0.83 & 0.81 \\
\hline Mean & 3.82 & 3.85 & 3.88 & & 0.74 & 0.76 & 0.78 & \\
\hline $\begin{array}{l}\text { C.D. } \\
(0.05)\end{array}$ & \multicolumn{4}{|c|}{$\mathbf{N}=0.18 \mathrm{~S}=0.04 \mathrm{~S}$ at $\mathrm{N}=0.05$} & \multicolumn{4}{|c|}{$\mathbf{N}=0.08 \mathrm{~S}=0.02 \mathrm{~S}$ at $\mathrm{N}=0.03$} \\
\hline
\end{tabular}

$\mathrm{N}=$ Nitrogen levels $\mathrm{S}=$ Sulphur levels $\mathrm{S}$ at $\mathrm{N}=$ Interaction of nitrogen at same level of sulphur.

Table 4. Interaction effect of QPM hybrids and sulphur on lysine (\%) and tryptophan (\%) (average of two years)

\begin{tabular}{|c|c|c|c|c|c|c|c|c|}
\hline \multirow[t]{2}{*}{ Treatment } & \multicolumn{4}{|c|}{ Lysine (\%) } & \multicolumn{4}{|c|}{ Tryptophan (\%) } \\
\hline & $\begin{array}{c}15 \mathrm{~kg} \mathrm{~S} \\
\mathrm{ha}^{-1}\end{array}$ & $\begin{array}{c}30 \mathrm{~kg} \mathrm{~S} \\
\mathrm{ha}^{-1}\end{array}$ & $\begin{array}{c}45 \mathrm{~kg} \mathrm{~S} \\
\mathrm{ha}^{-1}\end{array}$ & Mean & $\begin{array}{c}15 \mathrm{~kg} \mathrm{~S} \\
\mathrm{ha}^{-1}\end{array}$ & $\begin{array}{c}30 \mathrm{~kg} \mathrm{~S} \\
\mathrm{ha}^{-1}\end{array}$ & $\begin{array}{c}45 \mathrm{~kg} \mathrm{~S} \\
\mathrm{ha}^{-1}\end{array}$ & Mean \\
\hline Shaktiman-2 & 3.79 & 3.82 & 3.85 & 3.82 & 0.73 & 0.75 & 0.77 & 0.75 \\
\hline Shaktiman-4 & 3.85 & 3.88 & 3.91 & 3.88 & 0.75 & 0.77 & 0.79 & 0.77 \\
\hline Mean & 3.82 & 3.85 & 3.88 & & 0.74 & 0.76 & 0.78 & \\
\hline C.D. (0.05) & \multicolumn{4}{|c|}{$\mathbf{G}=0.05 \mathrm{~S}=0.04 \mathrm{~S}$ at $\mathrm{G}=0.05$} & \multicolumn{4}{|c|}{$\mathbf{G}=0.01 \mathrm{~S}=0.01 \mathrm{~S}$ at $\mathrm{G}=0.02$} \\
\hline
\end{tabular}

$\mathrm{G}=\mathrm{QPM}$ hybrids $\mathrm{S}=$ Sulphur levels $\mathrm{S}$ at $\mathrm{G}=$ Interaction of QPM hybrids at same level of sulphur.

\subsection{Economics}

Pooled data of 2 years showed that treatment $150 \mathrm{~kg} \mathrm{~N} \mathrm{ha}^{-1}$ gave remarkably higher net monetary returns Rs. $48720.39 \mathrm{ha}^{-1}$ and B: C ratio 2.63 followed by $100 \mathrm{~kg} \mathrm{~N}^{-1}$ and $50 \mathrm{~kg} \mathrm{~N} \mathrm{ha}^{-1}$ and lowest net return Rs. 17317.86 $\mathrm{ha}^{-1}$ and B: C ratio 1.61 was observed under $0 \mathrm{~kg} \mathrm{~N} \mathrm{ha}^{-1}$ (Table 5). Similar findings also reported by Sepat and Kumar, (2007). QPM hybrid Shaktiman-4 fetched the highest net monetary return Rs. $36246.01 \mathrm{ha}^{-1}$ and B: C ratio 2.22 over Shaktiman-2 (Table 6). Among sulphur levels highest mean value of net monetary return Rs. 37943.30 $\mathrm{ha}^{-1}$ and B: C ratio 2.24 was obtained with $45 \mathrm{~kg} \mathrm{~S} \mathrm{ha}^{-1}$ than the rest of sulphur treatments. Interaction effect of nitrogen $\times$ sulphur on net monetary returns and $\mathrm{B}$ : $\mathrm{C}$ ratio was found to be significant. The highest net monetary returns Rs. $56075.52 \mathrm{ha}^{-1}$ and B: C ratio 2.68 was obtained combination with $150 \mathrm{~kg} \mathrm{~N} \mathrm{ha}^{-1} \times 45 \mathrm{~kg} \mathrm{~S}^{-1}$ (Table 5). It might be due to highest yield under $150 \mathrm{~kg} \mathrm{~N} \mathrm{ha}^{-1}$ in combination with $45 \mathrm{~kg} \mathrm{~S}^{-1}$ leading to better net return and benefit: cost ratio. The findings indicate that the $150 \mathrm{~kg} \mathrm{~N} \mathrm{ha}^{-1}$ with $45 \mathrm{~kg} \mathrm{Sha}^{-1}$ was beneficial in term of grain yield, quality and economics of QPM hybrids under dryland condition. 
Table 5. Interaction effects of nitrogen and sulphur on Net return ( ha $\left.^{-1}\right)$ and B: C ratio of QPM hybrids (average of two years)

\begin{tabular}{|c|c|c|c|c|c|c|c|c|}
\hline \multirow[t]{2}{*}{ Treatment } & \multicolumn{4}{|c|}{ Net return $\left(\mathrm{ha}^{-1}\right)$} & \multicolumn{4}{|c|}{ B: $C$ ratio } \\
\hline & $\begin{array}{c}15 \mathrm{~kg} \mathrm{~S} \\
\mathrm{ha}^{-1}\end{array}$ & $\begin{array}{c}30 \mathrm{~kg} \mathrm{~S} \\
\mathrm{ha}^{-1}\end{array}$ & $\begin{array}{c}45 \mathrm{~kg} \mathrm{~S} \\
\mathrm{ha}^{-1}\end{array}$ & Mean & $\begin{array}{c}15 \mathrm{~kg} \mathrm{~S} \\
\mathrm{ha}^{-1}\end{array}$ & $\begin{array}{c}30 \mathrm{~kg} \mathrm{~S} \\
\mathrm{ha}^{-1}\end{array}$ & $\begin{array}{c}45 \mathrm{~kg} \mathrm{~S} \\
\mathrm{ha}^{-1}\end{array}$ & Mean \\
\hline $0 \mathrm{~kg} \mathrm{ha}^{-1}$ & 16741.15 & 17333.11 & 17879.30 & 17317.86 & 1.56 & 1.62 & 1.67 & 1.61 \\
\hline $50 \mathrm{~kg} \mathrm{ha}^{-1}$ & 31910.32 & 34224.28 & 35422.61 & 33852.41 & 2.13 & 2.17 & 2.21 & 2.17 \\
\hline $100 \mathrm{~kg} \mathrm{ha}^{-1}$ & 40414.75 & 41672.30 & 42395.78 & 41494.28 & 2.37 & 2.41 & 2.43 & 2.40 \\
\hline $150 \mathrm{~kg} \mathrm{ha}^{-1}$ & 43509.68 & 46575.98 & 56075.52 & 48720.39 & 2.60 & 2.61 & 2.68 & 2.63 \\
\hline Mean & 33143.97 & 34951.42 & 37943.30 & & 2.17 & 2.20 & 2.25 & \\
\hline $\begin{array}{l}\text { C.D. } \\
(0.05)\end{array}$ & \multicolumn{4}{|c|}{$\mathrm{N}=2455 \mathrm{~S}=1334 \mathrm{~S}$ at $\mathrm{N}=1775$} & \multicolumn{4}{|c|}{$\mathrm{N}=0.36 \mathrm{~S}=0.06 \mathrm{~S}$ at $\mathrm{N}=0.07$} \\
\hline
\end{tabular}

$\mathrm{N}=$ Nitrogen levels $\mathrm{S}=$ Sulphur levels, $\mathrm{S}$ at $\mathrm{N}=$ Interaction of nitrogen at same level of sulphur.

Table 6. Interaction effects of QPM hybrids and sulphur on Net return (' ha-1) and B: C ratio (average of two years)

\begin{tabular}{|c|c|c|c|c|c|c|c|c|}
\hline \multirow[t]{2}{*}{ Treatment } & \multicolumn{4}{|c|}{ Net return $\left(\mathrm{ha}^{-1}\right)$} & \multicolumn{4}{|c|}{ B: C ratio } \\
\hline & $\begin{array}{c}15 \mathrm{~kg} \mathrm{~S} \\
\mathrm{ha}^{-1}\end{array}$ & $\begin{array}{c}30 \mathrm{~kg} \mathrm{~S} \\
\mathrm{ha}^{-1}\end{array}$ & $\begin{array}{c}45 \mathrm{~kg} \mathrm{~S} \\
\mathrm{ha}^{-1}\end{array}$ & Mean & $\begin{array}{c}15 \mathrm{~kg} \mathrm{~S} \\
\mathrm{ha}^{-1}\end{array}$ & $\begin{array}{c}30 \mathrm{~kg} \mathrm{~S} \\
\mathrm{ha}^{-1}\end{array}$ & $\begin{array}{c}45 \mathrm{~kg} \mathrm{~S} \\
\mathrm{ha}^{-1}\end{array}$ & Mean \\
\hline Shaktiman-2 & 32862.99 & 34414.82 & 36062.01 & 34446.61 & 2.13 & 2.19 & 2.22 & 2.18 \\
\hline Shaktiman-4 & 33424.95 & 35487.99 & 39825.09 & 36246.01 & 2.19 & 2.20 & 2.26 & 2.22 \\
\hline Mean & 33143.97 & 34951.40 & 37943.55 & & 2.16 & 2.20 & 2.24 & \\
\hline C.D. (0.05) & \multicolumn{4}{|c|}{$\mathrm{G}=1023 \mathrm{~S}=1334 \mathrm{~S}$ at $\mathrm{G}=1685$} & \multicolumn{4}{|c|}{$\mathrm{G}=0.03 \mathrm{~S}=0.02 \mathrm{~S}$ at $\mathrm{G}=0.04$} \\
\hline
\end{tabular}

$\mathrm{G}=\mathrm{QPM}$ hybrids $\mathrm{S}=$ Sulphur levels $\mathrm{S}$ at $\mathrm{G}=$ Interaction of QPM hybrids at same level of sulphur.

\section{Conclusions}

Based on the above findings in respect of the yield, quality and economics, best results were achieved with QPM hybrid 'Shaktiman-4' along with application of $150 \mathrm{~kg} \mathrm{~N} \mathrm{ha}^{-1}+45 \mathrm{~kg} \mathrm{~S}^{-1}$ can be recommended for sustaining productivity and profitability under dryland condition of Eastern Uttar Pradesh of India.

\section{References}

Abdel-Wahab, A. F. M. (2008). Evaluation of enriched compost and its role in synergy with rhizobacteria and $\mathrm{N}$-fertilization for improving maize productivity in sandy soil. Journal of Agric. Sci., 16(2), 319-334.

Bharathi, C., \& Poongothai, P. (2008). Residual effect of sulphur application to maize on subsequent green gram in haplustalf. Legume Res., 31(3), 179-183.

Bhat, R. A., Altaf Wani, Beigh, M. A. H., \& Dawson, J. (2008). Integrated nitrogen management on the growth and yield of maize (Zea mays L.) under conditions of Uttar Pradesh. Asian J. of Hortic., 3(2), 229-231.

Cheema, H. S., \& Singh, B. (1991). Software Statistical Package CPCS-1. Department of Statistics, Punjab Agricultural University, Ludhiana, India.

Cochran, W. G., \& Cox, G. M. (1967). Experimental Designs. Asia Publishing House New Delhi.

Gaur, B. L., Mansion, P. R., \& Gupta, D. C. (1992). Effect of nitrogen levels and their splits on yield of winter maize, Indian J. Agron, 37(4), 816-817.

Hernandez, H., \& Bates, L. S. (1969). Determination of lysine, Res. Bull. CIMMYT, No.13.

Lohry, R. O. (1990). Effect of N fertilizer rate and nitropyrin on leaf chlorophyll, leaf N concentration and yield of three irrigated maize hybrid in Nebraska, Dissertation. Abs. Int. Sci. and Eng., 50(12), 5387B. 
Lucia, M., Maffia, Helen, E., Clark., \& Edwin, T. Mertz. (1976). Protein quality of two varieties of high-lysine maize fed alone and with black beans or milk to normal and depleted weanling rats., J. Clin. Nutr., 29, 817-824.

Meena, O., Khafi, H. R., Shekh, M. A., Mehta, A. C., \& Davda, B. K. (2007). Response of rabi maize (Zea mays L.) to vermicompost and nitrogen levels. Crops Res., 8(1), 93-94.

Mehta, Y. K., Shaktawat, M. S., \& Singhi, S. M. (2005). Influence of sulphur, phosphorus and farmyard manure on yield attributes and yield of maize (Zea mays) in southern Rajasthan conditions. Indian J. of Agron., 50(3), 203-205.

Onasanya, R. O., Aiyelari, O. P., Onasanya, A., Oikeh, S., Nwilene, F. E. N., \& Oyelakin, O. O. (2009). Growth and Yield Response of Maize (Zea mays L.) to Different Rates of Nitrogen and Phosphorus Fertilizers in Southern Nigeria. World J. of Agric. Sci., 5(4), 400-407.

Pixley, K. V., \& Bjarnason, M. S. (2002). Stability of grain yield, endosperm modification and protein quality of hybrids and open-pollinated quality protein maize (QPM) cultivers. Crop Sciences, 42(6), 1882-1890.

Rana, K. S., \& Choudhary, R. S. (2006). Productivity, nitrogen uptake and water use in maize (Zea mays L.) + mungbean intercropping system as affected by nitrogen levels under rainfed conditions. Crop Res.(Hisar)., 32(3), 306-308.

Rasheed, M. Ali, H., \& Tariq., M. (2004). Impact of nitrogen and sulfur application on growth and yield of maize (Zea mays L.) J. of Crop Res. (Science), 15(2), 153-157.

Sakal, R., Sinha, R. B., Singh, A. P., Bhogal, N. S., \& Ismail, M. D. (2000). Influence of sulphur on yield and mineral nutrition of crops in maize-wheat sequence. Journal of the Indian Society of Soil Sci., 48(2), 325-329.

San Vicente, G. F. M., Marin, R. C., \& Diaz, D. (2005). Yield stability and agronomic potential of QPM maize hybrids in Venezuela. Agronomia Tropic crop, 55(3), 397-410.

Sepat, A., \& Kumar, A. (2007). Influence of irrigation and nitrogen management on yield and economics of maize (Zea mays L.). Crop Res.(Hisar)., 33(1/3), 50-52.

Sharma, P., Abrol, V., \& Sharma, R. K. (2011). Impact of tillage and mulch management on economics, energy requirement and crop performance in maize- wheat rotation in rainfed subhumid inceptisols, India. Europ. $J$. Agronomy, 31, 46-51.

Srivastava, A., Jat, M., Zaidi, P. H., Rai, H. K., Gupta, R. K., Sharma, S. K., \& Srinivasan, G. (2005). Screening of quality protein maize hybrids with different resource conserving technologies- Paper presented in the $9^{\text {th }}$ Asian Regional Maize work shop Sept. 6-9 Beijing, China.

Upadhyay, S. R., Koirala, K. B., Pandel, D. C., Sah, S. N., Sharma, D., Gurung, D. B., ... Sharma, R. C. (2008). Performance of quality protein maize (QPM) QPM hybrids in the warm rainfed hill environments in Nepal. Asian J. Plant Sci., 7(4), 375-381.

Villegas, E., \& Mertz, E. T. (1971). Determination of tryptophan, Res. Bull. CIMMYT, No. 20. 